\title{
Blood Pressure Control in Neurological ICU Patients: What is Too High and What is Too Low?
}

\author{
Gulrukh Zaidi $^{*}$, , Astha Chichra ${ }^{1}$, Michael Weitzen ${ }^{2}$ and Mangala Narasimhan ${ }^{1}$ \\ ${ }^{I}$ The Division of Pulmonary, Critical Care and Sleep Medicine, The North Shore, Long-Island Jewish Health System, \\ The Hofstra-North Shore LIJ School of Medicine, USA \\ ${ }^{2}$ Department of Surgery, Phelps Memorial Hospital, USA
}

\begin{abstract}
The optimal blood pressure (BP) management in critically ill patients with neurological emergencies in the intensive care unit poses several challenges. Both over and under correction of the blood pressure are associated with increased morbidity and mortality in this population. Target blood pressures and therapeutic management are based on guidelines including those from the American Stroke Association and the Joint National Committee guidelines. We review these recommendations and the current concepts of blood pressure management in neurological emergencies. A variety of therapeutic agents including nicardipine, labetalol, nitroprusside are used for blood pressure management in patients with ischemic and hemorrhagic strokes. Currently, the role of inducing hypertension remains unclear. Hypertensive crises include hypertensive urgencies where elevated blood pressures are seen without end organ damage and can usually be managed by oral agents, and hypertensive emergencies where end organ damage is present and requires immediate treatment with intravenous drugs.
\end{abstract}

Keywords: Ischemic stroke, hemorrhagic stroke, hypertension, hypotension, thrombolytic therapy, hypertensive urgency and emergency, posterior reversible encephalopathy syndrome.

\section{INTRODUCTION}

The optimization of blood pressure in patients admitted to the Intensive Care Unit (ICU) with neurological emergencies is challenging. Both over and under correction of the blood pressure are associated with increased morbidity and mortality. Moreover, due to a paucity of data from sufficiently powered randomized controlled trials, the guidelines for blood pressure management are usually based on small studies and expert opinion. This review discusses the presentation and pathophysiological basis for blood pressure abnormalities and outlines the approach to blood pressure management in both ischemic and hemorrhagic strokes.

\section{STROKE}

Stroke or a cerebrovascular accident is a leading cause of disability and the third leading cause of death in the United States. It is defined by an abrupt onset of a neurologic deficit that is attributable to a focal vascular cause. $80 \%$ of strokes are caused by focal cerebral ischemia due to arterial occlusion, and the remaining $20 \%$ are caused by hemorrhages $[1,2]$.

Blood pressure abnormalities are a common feature in patients presenting with acute stroke. Strategies for blood pressure management are different for patients with ischemic strokes compared to those with hemorrhagic strokes.

*Address correspondence to this author at the Division of Pulmonary, Critical Care and Sleep Medicine, The North Shore, Long-Island Jewish Health System, The Hofstra-North Shore LIJ School of Medicine, USA; Tel: 516-465-5400 Fax: 516-465-5454; E-mail: gzaidi@nshs.edu
However, an understanding of cerebral autoregulation is essential prior to discussing the management of either hyper or hypotension in these patients.

\section{Cerebrovascular Pathophysiology}

To understand blood pressure management in acute CVA, it is important to fully understand cerebrovascular physiology. Under normal physiological conditions, cerebral perfusion pressure (CPP) is defined as the difference between the systemic mean arterial pressure (MAP) and the intracranial pressure (ICP). The brain has the ability to adjust the downstream cerebrovascular resistance by reflex vasoconstriction or vasodilation of the cerebral arterioles in response to changes in perfusion pressure; a process known as autoregulation. Normally, the cerebral blood flow (CBF) remains relatively constant at about $50 \mathrm{ml}$ per $100 \mathrm{~g}$ tissue per minute across a wide range of MAP [3].

Evidence indicates that autoregulation is dysfunctional after a stroke. If capacity for autoregulation does not exist, $\mathrm{CBF}$ increases or decreases proportionally to the MAP exposing the brain to ischemia from hypoperfusion, or edema and hemorrhage in the case of an elevated MAP [4].

\section{BLOOD PRESSURE MANAGEMENT IN ISCHEMIC STROKE}

Acute elevations in blood pressure occur in $75 \%$ to $80 \%$ of patients with acute stroke. The blood pressure usually decreases spontaneously over the next 7-10 days [5]. This post stroke hypertension is likely a compensatory response to maintain and even increase CPP and CBF to the ischemic penumbra. However other mechanisms including stress, 
pain, nausea, urinary retention and elevated intracranial pressure have also been postulated.

Numerous studies examining the relationship between admission or early changes in blood pressure and outcome after stroke have shown a U-shaped relationship between presenting BP and outcome after ischemic stroke. In these studies extremes of blood pressure, both high and low, were associated with a poor outcome [6-10]. A study by LeonardiBee and co-workers demonstrated that for every $10 \mathrm{mmHg}$ increase in SBP above $150 \mathrm{mmHg}$ the risk of early death increased by $3.8 \%$. Additionally for every $10 \mathrm{mmHg}$ of SBP below $150 \mathrm{mmHg}$, the risk of early death increased by $3.6 \%$ and the risk of late death and dependency increase by $17.9 \%$ [6]. Low blood pressure may lead to cerebral hypoperfusion and increased likelihood of cardiac events, whereas high blood pressure may cause worsening cerebral edema, with both leading to poorer outcomes [6-10].

In the following sections we will review the approach to blood pressure management in patients with acute ischemic strokes who received thrombolytic therapy as well as those who did not.

\section{Blood Pressure Management Following Thrombolytic Therapy}

Randomized, controlled trials demonstrated that intravenous rtPAtherapy is beneficial for select patients with acute ischemic stroke who receive treatment within 4.5 hours of symptom onset at designated stroke centers.

Strict blood pressure control is critical prior to and during the first 24 hours following thrombolytic therapy as uncontrolled blood pressure increases the risk of intracranial hemorrhage in this population [5]. Patients with a blood pressure above $185 / 110 \mathrm{mmHg}$ should be treated with intravenous labetalol or intravenous nicardipine. If this does not lower the blood pressure into the acceptable range, the patient should not receive rtPA [5].

Once thrombolytic therapy has been administered the blood pressure should be aggressively controlled over the next 24 hours and must be maintained below 180/105 mmHg during this period. Frequent blood pressure monitoring is recommended to ensure that the blood pressure remains in the acceptable range and that hypotension due to over treatment does not occur [5].

\section{Blood Pressure Management in Patients Not Receiving Thrombolytic Therapy}

Studies on the management of hypertension in ischemic stroke have arrived at conflicting conclusions and only a few randomized trials of blood pressure lowering in acute ischemic stroke have been published [11-15].

In a randomized placebo-controlled trial involving 350 patients oral nimodipine was started within 48 hours after ischemic stroke onset [11]. The nimodipine group had significantly lower systolic and diastolic blood pressures. However, the functional outcome at 3 months was similar in the 2 treatment groups and a significantly higher mortality rate was observed in the nimodipine group [11].

The Scandinavian Candesartan Acute Stroke Trial (SCAST) randomly allocated 2029 patients with acute ischemic or hemorraghic strokes and a systolic BP $>140$
mmHg within 30 hours (mean time 18 hours) of symptom onset, to receive either candesartan or placebo. They achieved a mean systolic BP difference of $5 \mathrm{mmHg}(\mathrm{p}<$ 0.0001 ) between groups over 7 days. During the 6-month follow-up, the risk of the composite vascular endpoint did not differ between treatment groups but the analysis of functional outcome suggested a higher risk of poor outcome in the candesartan group [12].

The CHHIPS trial enrolled 179 adults with ischemic stroke or cerebral hemorrhage (approximately 14 percent) and an admission systolic blood pressure (SBP) $>160$ $\mathrm{mmHg}$. Patients were randomly assigned to antihypertensive therapy (target SBP 145 to $155 \mathrm{mmHg}$ ) with labetolol, lisinopril or placebo within 36 hours of symptom onset. There was no significant difference in early neurologic deterioration at 72 hours between the antihypertensive treatment and placebo groups ( 6 versus 5 percent). However, there were few outcome events, and the confidence intervals were wide. In addition, the trial excluded some patients on pre-existing antihypertensive therapy, a group that might be expected to deteriorate with blood pressure lowering in the early phases of ischemic stroke [13].

The Continue or Stop Post-Stroke Antihypertensives Collaborative Study (COSSACS) enrolled patients on antihypertensive medications within 48 hours of ischemic or hemorrhagic stroke. The patients were randomly assigned to either continue or stop antihypertensive drugs. At two weeks, there was no significant difference between groups for the primary outcome of death or dependency; the difference between the 'continue' and 'stop' groups for systolic (13 $\mathrm{mmHg}$ ) and diastolic (8 $\mathrm{mmHg})$ blood pressure was significant [14].

The Efficacy of Nitric Oxide in Stroke (ENOS) trial is an ongoing study which aims to assess the effects of treatment with $5 \mathrm{mg}$ transdermal glyceryltrinitrate (GTN) over 7 days in hypertensive patients with acute stroke (IS and ICH) presenting within 48 hours of symptom onset. In addition, a subgroup of patients previously on antihypertensive treatment will also be randomized into temporarily stopping or continuing antihypertensive medication. The results of this study, with over 3000 of the required sample size of 3500 patients currently included, should provide valuable information on the effects of acute BP management in patients with an acute stroke [15].

Therefore, the optimal management of blood pressure in the setting of an acute ischemic stroke remains controversial. Most of the randomized control trials included patients with intracerebral hemorrhage, a group that might be expected to benefit from early blood pressure lowering. Additionally, treatment at earlier time points, for example within the first 12 hours, when patients may be more susceptible to deterioration following blood pressure lowering, may have been under-represented in these trials.

\section{Current Recommendations for Blood Pressure Management}

For patients with acute ischemic stroke who are not treated with rtPA the American Stroke Association (ASA) and European Stroke Organization (ESO) guidelines recommend cautiously lowering the blood pressure only if it is greater than $220 / 120 \mathrm{~mm} \mathrm{Hg} \mathrm{[16]} \mathrm{or} \mathrm{if} \mathrm{the} \mathrm{patient} \mathrm{has}$ 
another clear indication such as active ischemic coronary disease, heart failure, aortic dissection, hypertensive encephalopathy, acute renal failure, or preeclampsia/eclampsia [5, 17]. When treatment is indicated, the blood pressure should be cautiously lowered by approximately 15 percent during the first 24 hours following stroke onset [17].

\section{Choice of Antihypertensive Agent}

In order to avoid a precipitous drop in pressure that could further worsen cerebral ischemia, it is necessary to use treatments that can be easily controlled. Intravenous labetalol is generally the first drug of choice in the acute phase, since it allows rapid and safe titration to the goal blood pressure. Other first line agents include nicardipine and in certain cases hydralazine and enalaprilat may be considered [5]. The choice of the agent is also determined by cost and familiarity.

Intravenous nitroprusside should be considered secondline therapy since it carries the added theoretical risks of increasing intracranial pressure or affecting platelet function. Short-acting formulations of nifedipine should be avoided because they cause a prolonged and precipitous decline in blood pressure [5]. In addition, their use is associated with an increased risk of stroke, particularly in elderly patients [18]. Table 1 summarizes the commonly used agents for blood pressure control in acute stroke patients.

\section{TREATMENT OF RELATIVE HYPOTENSION}

Hypotension is relatively uncommon in stroke patients and is associated with an increased risk for early and late death. Potential etiologies of hypotension such as hypovolemia, hemorrhage, arrhythmias, decompensated congestive heart failure and aortic dissection should be diagnosed and corrected.

If hypotension develops post thrombolysis, extracranial hemorrhage or hemopericardium with cardiac tamponade should be considered and the appropriate investigations should be pursued.

Occasionally, patients may benefit from pharmacologic increases in blood pressure. Small studies identified a systolic blood pressure threshold below which ischemic deficits worsened [19-23]. In a retrospective review of 63 patients with ischemic stroke, 30 were treated with phenylephrine within 12 hours of symptom onset and 33 were not given pressor support. The authors found no significant difference in the morbidity or mortality between the 2 groups. In 10 of 30 patients treated with induced hypertension, a systolic blood pressure threshold (mean 156 $\mathrm{mmHg}$ ) was identified below which ischemic deficits worsened and above which deficits improved. The mean number of stenotic arteries was greater in patients with an identified clinical blood pressure threshold for improvement subsequent to induced hypertension [19].

In a second pilot study, Rordorf et al. also used phenylephrine to raise the systolic blood pressure in patients with acute stroke by $20 \%$, but not to exceed $200 \mathrm{~mm} \mathrm{Hg}$. Of the 13 patients treated, 7 improved by 2 points on the NIHSS and no systemic or neurologicalcomplications were observed [20].

The feasibility and safety of induced arterial hypertension (10 to $20 \%$ of the initial value) in the acute phase of ischemic stroke were retrospectively evaluated in 34 patients treated with norepinephrine (NE) for a median of 26 hours. The maximal variability of systolic blood pressure during NE application was within $15 \%$ of the target values. Early (within 8 hours of initiation) neurological improvement by $\geq 2$ points on the NIHSS was seen in $9(27 \%)$ of 33 patients. Intracranial hemorrhage occurred in 2 patients and one patient developed a cardiac arrhythmia [21].

Hillis et al. [22] conducted a pilot, randomized trial to evaluate effects of pharmacologically induced blood pressure elevation on function and perfusion in acute stroke. Consecutive series of patients with large diffusion-perfusion mismatch were randomly assigned to induced blood pressure elevation ('treated' patients, $\mathrm{n}=9$ ) or conventional management ('untreated' patients, $\mathrm{n}=6$ ). Diffusion weighted imaging and perfusionweighted MRI studies were performed before and during the period of induced hypertension. Patients who were treated with induced hypertension showed significant improvement in NIHSS score from day 1 to day 3, cognitive score, and volume of hypoperfused tissue. High correlations were observed between the mean arterial pressure and accuracy on daily cognitive tests [22].

Table 1. Commonly Used Medications for Blood Pressure Control in Acute Stroke Patients

\begin{tabular}{|c|c|c|}
\hline Labetolol & $\begin{array}{l}\text { - Initial dose of } 10 \text { to } 20 \mathrm{mg} \text { intravenously over } 1 \text { to } 2 \text { minutes } \\
\text { - If needed can be followed by an intravenous infusion at } 2 \text { to } 8 \\
\mathrm{mg} / \mathrm{min} \\
\text { - Aim for a } 10 \% \text { to } 15 \% \text { reduction in blood pressure }\end{array}$ & $\begin{array}{l}\text { Aggravation of asthma, bradycardia, congestive } \\
\text { heart failure. }\end{array}$ \\
\hline Nicardipine & $\begin{array}{l}\text { - } 5 \text { to } 10 \mathrm{mg} / \mathrm{h} \text { by infusion initially } \\
\text { - Titrate dose to target blood pressure by increasing } 2.5 \mathrm{mg} / \mathrm{h} \text { every } 5 \\
\text { minutes to a maximum of } 15 \mathrm{mg} / \mathrm{h} \\
\text { - Aim for a } 10 \% \text { to } 15 \% \text { reduction in blood pressure }\end{array}$ & Tachycardia, aggravation of angina. \\
\hline Sodium Nitroprusside & $\begin{array}{l}\text { - Initially, } 0.5 \mathrm{ug} / \mathrm{kg} / \mathrm{min} \text { by intravenous infusion, with constant } \\
\text { monitoring of blood pressure } \\
\text { - Titrate dose to achieve target blood pressure (up to } 8 \mathrm{ug} / \mathrm{kg} / \mathrm{min} \\
\text { - Aim for a } 10 \% \text { to } 15 \% \text { reduction in blood pressure }\end{array}$ & $\begin{array}{l}\text { Cyanide toxicity } \\
\text { Potential increase in intracranial pressure } \\
\text { Potential platelet dysfunction }\end{array}$ \\
\hline
\end{tabular}


Koenig et al. [23] reported the analysis of 100 patients who underwent perfusion-weighted MRI after acute ischemic stroke. 46 of these patients were treated with induced hypertension with various vasopressors. The target mean arterial pressure augmentation of $10 \%$ to $20 \%$ above baseline was achieved in $35 \%$ of the 46 treated patients. Compared with 54 patients who underwent conventional treatment, NIHSS scores were similar during hospitalization and discharge, with no clear difference in rates of adverse events.

Theoretically, vasopressor-induced hypertension is an attractive method to increase CPP and CBF to the ischemic penumbra. However, the potential adverse affects of vasopressors including hemorrhagic conversion, cardiac ischemia, renal dysfunction and cerebral edema may counteract the potential benefits.

The available evidence suggests that a small subset of patients with ischemic stroke in the very acute period may benefit from modest $(10 \%-20 \%)$ pharmacological elevation in systemic blood pressure. No clear criteria are validated for selection of such patients, although patients with large perfusion deficits caused by steno-occlusive disease who are not candidates for fibrinolytic and interventional treatments are the most often studied, as well as those patients who demonstrate neurological change that correlates with systemic blood pressure changes. A short period (30-60 minutes) of a vasopressor infusion trial may help identify patients who are potential responders to such treatment [5].

\section{HEMORRHAGIC STROKE}

Twenty percent of strokes are hemorrhagic, with subarachnoid hemorrhage (SAH) and intracerebral hemorrhage each accounting for 10 percent.

\section{Subarachnoid Hemorrhage}

Most SAHs are caused by ruptured saccular aneurysms. Other causes include trauma, arteriovenous malformations, vasculitides, intracranial arterial dissections, amyloid angiopathy, bleeding diatheses, and illicit drug use. The overwhelming majority of patients present with a sudden onset of severe headache, which may be associated with brief loss of consciousness, seizures, nausea, vomiting, or meningismus. Noncontrast head CT reveals the diagnosis in more than 90 percent of cases if performed within 24 hours of bleeding onset. A lumbar puncture is mandatory if there is a strong suspicion of SAH despite a normal head CT. The classic findings are an elevated opening pressure and an elevated red blood cell count that does not diminish from CSF tube one to tube four.

Patients with SAH are usually admitted to an intensive care unit for continuous hemodynamic and neurologic monitoring. Complications of SAH include rebleeding, vasospasm, delayed cerebral ischemia, hydrocephalus, increased intracranial pressure, seizures, hyponatremia, cardiac abnormalities, hypothalamic dysfunction and pituitary insufficiency. Surgical clipping and endovascular coiling are effective in preventing rebleeding in aneurysmal bleeds and should be performed early.

\section{Blood Pressure Management in SAH}

The blood pressure is elevated in 56- $100 \%$ of patients during the acute phase of a SAH [24]. Although evidence demonstrating an association between increased BP and aneurysm rebleeding is limited [25,26], one study suggested that SBP greater than $160 \mathrm{mmHg}$ is a risk factor for rebleeding in the acute phase of SAH [27]. Another retrospective study reported that treating hypertension in SAH lowered the risk of rebleeding but increased the risk of ischemic stroke and did not improve 3-month clinical outcome [28].

Although, the optimal therapy of hypertension in SAH is not clear, when blood pressure control is necessary, labetalol is the preferred agent. The use of vasodilators such as nitroprusside or nitroglycerin should be avoided because of their propensity to increase cerebral blood volume and therefore intracranial pressure.

During hospitalization, symptomatic vasospasm with delayed cerebral ischemia is a major complication accounting for up to $50 \%$ of deaths in SAH patients surviving to hospitalization. For patients with symptomatic vasospasm and a secured aneurysm, therapeutic hypertension may be beneficial. The goal is to prevent infarction by increasing MAP, and thus $\mathrm{CBF}$, until neurological changes are reversed. A possible target range for SBP is 160$180 \mathrm{mmHg}$, but this goal should be individualized based on age, severity, and cardiovascular comorbidities [29-31]. Therapeutic hypertension should be avoided in the setting of an unsecured aneurysm because of the risk of rebleeding [2931].

\section{Epidural and Subdural Hemorrhage}

Epidural hemorrhage is defined as blood in the potential space between the dura and the skull and is usually due to of traumatic injury. Patients with focal neurologic signs or symptoms should have emergent surgical hematoma evacuation [32-34].

Subdural hemorrhage $(\mathrm{SDH})$ is bleeding in the space between the dura and the arachnoid membranes. The mortality of acute SDH requiring surgery is high ranging between 40 and $60 \%$. Age and neurologic status, as assessed with the Glasgow coma scale, are important prognostic indicators. Urgent surgical hematoma evacuation is generally recommended for patients who have evidence of neurologic deterioration since the time of injury and the potential for recovery [33]. Nonoperative management is generally suggested for patients who are clinically stable or improving or have no signs of brain herniation [34].

\section{Intracranial Hemorrhage}

Hypertensive vasculopathy is the most common etiology of spontaneous intracerebral hemorrhage (ICH). Other causes include cerebral amyloid angiopathy and vascular malformations. Patients typically present with an acute onset of a focal neurologic deficit that corresponds to the part of the brain affected. With large hemorrhages, there is elevated intracranial pressure and suppressed level of consciousness. Seizures may also complicate 5 to 30 percent of hemorrhages. A noncontrast brain computed tomogram (CT) 
in patients with this presentation will usually demonstrate the hematoma.

The mean arterial pressure (MAP) is often elevated in patients with $\mathrm{ICH}$ and may provide a continued force for bleeding [35-37]. However, an increased MAP may also be necessary to maintain cerebral perfusion and aggressive lowering the arterial pressure could result in ischemia and worsen neurologic injury.

\section{Blood Pressure Management in ICH}

Limited prospective data are available regarding BP management in ICH. The Intensive Blood Pressure Reduction in Acute Cerebral Hemorrhage Trial (INTERACT) randomized 404 patients with $\mathrm{ICH}$ to intensive blood pressure lowering treatment (systolic blood pressure $(\mathrm{SBP})<140 \mathrm{mmHg}$ ) compared with traditional management (target SBP $<180 \mathrm{mmHg}$ ). This study demonstrated a reduction in hematoma growth at 24 hours with intensive BP lowering (14 versus 26 percent), however, this finding did not achieve statistical significance after adjustment for initial hematoma volume and time from $\mathrm{ICH}$ onset to head CT [35-37]. There was also no effect of treatment on clinical outcomes at 90 days [36]. Smaller, nonrandomized studies have also found that more aggressive BP lowering is associated with strong trends toward reduced hematoma enlargement [35-39].

The INTERACT 2 trial provides the best available evidence on acute blood-pressure management following ICH [40]. The investigators randomized 2839 patients who had a spontaneous ICH within the previous 6 hours and who had elevated systolic blood pressure to receive intensive treatment to lower their blood pressure (with a target systolic level of $<140 \mathrm{~mm} \mathrm{Hg}$ within 1 hour) or guidelinerecommended treatment (with a target systolic level of $<180$ $\mathrm{mm} \mathrm{Hg}$ ) using agents of the physician's choosing. The investigators found that blood pressure lowering therapy was safe as there were no significant differences between those receiving intensive blood pressure lowering treatment and those receiving the standard treatment with respect to outcomes such as neurologic deterioration, expansion of the intracerebral hemorrhage, ischemic stroke, cardiovascular events, or severe symptomatic hypotension. The primary end point was the modified Rankin scale (MRS). The MRS is a commonly used scale for measuring the degree of disability or dependence in daily activities in those who had suffered a neurological disability. The MRS showed a trend toward significance $(\mathrm{P}=0.06)$. However, when the end point was examined from a different prespecified vantage point - an ordinal analysis of the MRS (which has inherently better power to show effect) — there was a significant improvement in the outcome with intensive blood pressure lowering therapy [40, 41].

Labetalol, nicardipine, esmolol, enalapril, hydralazine, nitroprusside, and nitroglycerin are useful intravenous agents for controlling blood pressure [38]. The current guidelines for managing elevated blood pressure in acute spontaneous ICH are summarized in Table 2.

\section{SUMMARY}

- $\quad$ Extremes of blood pressure in acute ischemic stroke are associated with poor outcomes and should be avoided. The BP in patients receiving thrombolytic therapy should be strictly maintained below 180/110 $\mathrm{mmHg}$. In patients not receiving thrombolytic therapy, the BP should be cautiously lowered only if it is greater than $220 / 120 \mathrm{mmHg}$.

- It remains unclear if the induction of hypertension is beneficial in relatively hypotensive ischemic stroke patients. Currently there is not sufficient evidence to recommend this in clinical practice.

- In patients with acute SAH lowering the SBP below $160 \mathrm{mmHg}$ may reduce the risk of aneurysmal rebleeding. In patients with a secured aneurysm and symptomatic vasospasm the systolic BP should be maintained in the range of 160-180 $\mathrm{mmHg}$.

- Intensive blood pressure lowering to a target systolic blood pressure of $140 \mathrm{mmHg}$ in patients with acute $\mathrm{ICH}$ appears to be safe and could reduce long term functional disability.

\section{HYPERTENSIVE CRISIS}

Because of advances in hypertensive therapy, only $1 \%$ of hypertensive patients will develop a hypertensive crisis. However, approximately $25 \%$ of neurological admissions from the emergency department are related to hypertensive crisis [42]. There is confusion in the literature on terminology. According to the Seventh Report of the Joint National Committee on Detection, Evaluation and Treatment of High Blood Pressure, hypertensive crisis is divided into either hypertensive urgency or emergency. Hypertensive urgency involves an elevated systolic pressure $>180 \mathrm{~mm} \mathrm{Hg}$ or diastolic pressure $>110 \mathrm{~mm} \mathrm{Hg}$, in the absence of end organ damage or

Table 2. Summarizing Current Guidelines for BP Management in Patients with ICH

\begin{tabular}{|l|l|}
\hline \multicolumn{1}{|c|}{ Blood Pressure } & Current Guidelines \\
\hline \hline $\begin{array}{l}\mathrm{SBP}>200 \mathrm{mmHg} \text { or } \\
\mathrm{MAP}>150 \mathrm{mmHg}\end{array}$ & $\bullet \begin{array}{l}\text { Aggressive reduction in blood pressure with intravenous infusions } \\
\text { Blood pressure monitoring every five minutes. }\end{array}$ \\
\hline $\begin{array}{l}\mathrm{SBP}>180 \mathrm{mmHg} \text { or MAP }>130 \mathrm{mmHg} \text { and no evidence or } \\
\text { uspicion of elevated ICP }\end{array}$ & $\begin{array}{l}\text { Blood pressure should be modestly reduced to a target } \mathrm{MAP} \text { of } 110 \mathrm{mmHg} \text { or target } \\
\text { blood pressure of } 160 / 90 \mathrm{~mm} \text { with intravenous medications } \\
\text { Reexamination and blood pressure monitoring should be performed every } 15 \\
\text { minutes }\end{array}$ \\
\hline $\begin{array}{l}\text { Evidence of elevated ICP and SBP }>180 \mathrm{mmHg} \text { or MAP }>130 \\
\mathrm{mmHg}\end{array}$ & $\bullet \begin{array}{l}\text { ICP should be monitored } \\
\text { Blood pressure reduction should target a CPP in the range of } 61 \text { to } 80 \mathrm{mmHg}\end{array}$ \\
\hline
\end{tabular}

Blood pressure (BP), systolic blood pressure (SBP), mean arterial pressure (MAP), intracranial pressure (ICP), cerebral perfusion pressure (CPP) 
Table 3. Differentiation Between Hypertensive Crises

\begin{tabular}{|l|c|c|}
\hline & Emergency & Urgency \\
\hline \hline Presentation & Frequently associated with signs and symptoms & Less frequent \\
\hline Acute end organ damage & Yes & No \\
\hline Acute Blood Pressure Control & Yes & No \\
\hline Intravenous medications & Yes & No \\
\hline Hospitalization & ICU admission & $\begin{array}{c}\text { May be discharged from emergency room with follow up within 1 } \\
\text { week }\end{array}$ \\
\hline
\end{tabular}

dysfunction [43]. Patients presenting with hypertensive urgency may experience headache, shortness of breath or nose bleeds. When end organ damage/dysfunction is present, the classification is hypertensive emergency. A common manifestation of hypertensive emergency is hypertensive encephalopathy, which is related to cerebral edema. The edema is believed to result from loss of vascular autonomic regulation in the setting of severely elevated blood pressure. Clinically it manifests with nausea, vomiting, severe headache and/or altered mental status/seizure. One should keep in mind that hypertensive emergency does not specify a specific blood pressure level and may occur in normotensive or previously well controlled hypertensive patients with only a modest rise in blood pressure [44]. End organ damage or dysfunction, rather than the absolute degree of blood pressure elevation, dictates the manner in which blood pressure should be controlled (Table 3).

Hypertensive crises are usually found in non-compliant patients with chronic hypertension (essential or secondary). It may also be the first presentation of previously unrecognized hypertension. An acute increase in systemic vascular resistance related to humoral vasoconstrictors leads to an abrupt increase in BP which generates mechanical stress and endothelial injury resulting in increased permeability, activation of the coagulation cascade and platelets, and deposition of fibrin. This results in ischemia and the release of additional vasoactive mediators thus generating a vicious cycle of ongoing endothelial injury [45]. The renin-angiotensin system is activated, leading to further vasoconstriction and the production of proinflammatory cytokines such as interleukin-6. Pressure natriuresis in turn leads to volume depletion further stimulating the release of vasoconstrictor substances from the kidney [46]. These mechanisms collectively lead to the end-organ hypoperfusion, ischemia and dysfunction, all of which manifest as a hypertensive emergency.

\section{Clinical Evaluation}

Patients presenting with high blood pressure (usually defined as a systolic blood pressure $>180$ and/or a diastolic blood pressure $>110$ ) should be triaged earlier. History and physical assessment (Table 4) should focus on signs and symptoms related to end organ damage. These include: Headache, nausea, vertigo, chest pain, back pain, shortness of breath, blurry vision, prior history of hypertension, medications, over-the-counter and illegal drug use. Patient adherence with their antihypertensive medications should be addressed as sudden withdrawal of these agents can precipitate such crises.
Table 4. Manifestations of End Organ Damage/ Target Organ Dysfunction

\author{
Neurological \\ Neurological deficit/Stroke \\ Loss of Consciousness \\ Delirium \\ Seizure \\ Vertigo \\ Cardiac \\ Angina \\ Heart Failure \\ Pulmonary Edema \\ Aortic Dissection \\ Renal \\ Loss of kidney function \\ Hematuria \\ Eyes \\ Papillary edema \\ Bleed in the vessels \\ Pregnancy \\ Eclampsia
}

Initial assessment should be directed towards finding neurological deficits and determining the volume status of the patient. Fundoscopic examination should be performed in every patient. Grade III (presence of hemorrhages, cotton wool spots, yellow-white exudates) and grade IV (papilledema accompanied by hemorrhages and exudates) retinopathies are the hallmarks of hypertensive emergency. Blood pressure should be taken in both arms and similarly bilateral radial and femoral pulses should be checked. A significant discrepancy $(>20 \mathrm{~mm} \mathrm{Hg}$ in systolic pressures) between arms or lack of femoral pulses is suggestive of aortic dissection. Cardiovascular auscultation may reveal new murmurs. A diastolic murmur may be due to aortic insufficiency in the setting of aortic dissection, while a systolic murmur from mitral regurgitation may be the result of papillary muscle rupture due to myocardial ischemia. Signs of heart failure include: elevated jugular venous pressure, an S3 gallop, and the presence of rales on lung examination. An abdominal bruit may suggest renovascular disease as the cause of hypertension. Delirium or a flapping tremor is suggestive of hypertensive encephalopathy. However, hypertensive encephalopathy is a diagnosis of exclusion and other intracranial pathology such as stroke or subarachnoid hemorrhage should be excluded. 
Table 5A. Parental Medications for Hypertensive Emergency

\begin{tabular}{|c|c|c|c|c|c|}
\hline Drug & Mechanism of Action & Dosage & Onset & Duration of Action & Adverse Reactions \\
\hline \multicolumn{6}{|l|}{$\begin{array}{l}\text { Sympathetic } \\
\text { Blockers }\end{array}$} \\
\hline Esmolol & Beta Blocker & $\begin{array}{l}\text { Bolus with } 50-500 \\
\text { microgram } / \mathrm{kg} / \mathrm{min} \text { and } / \text { or } \\
50-100 \mathrm{mcg} / \mathrm{kg} / \mathrm{min} \\
\text { infusion and } \mathrm{may} \text { increase } \\
\text { upto } 300 \mathrm{mcg} / \mathrm{kg} / \mathrm{min} \text {; } \\
\text { repeat bolus } \mathrm{q} 5 \mathrm{~min}\end{array}$ & $1-2 \mathrm{~min}$ & $10-30$ minutes & $\begin{array}{l}\text { Bronchial Asthma, } \\
\text { Heart Failure, } \\
\text { Nausea }\end{array}$ \\
\hline Labetolol & Alpha, Beta blocker & $\begin{array}{l}20-80 \mathrm{mg} \text { bolus q10 } \mathrm{min} \\
0.5-2.0 \mathrm{mg} / \mathrm{min} \text { infusion }\end{array}$ & $5-10 \mathrm{~min}$ & 2-6 hours & $\begin{array}{l}\text { Bronchospasm, } \\
\text { nausea, vomiting, } \\
\text { scalp tingling }\end{array}$ \\
\hline Phentolamine & Alpha blocker & $5-15 \mathrm{mg}$ bolus & $1-2 \mathrm{~min}$ & $10-30 \mathrm{~min}$ & $\begin{array}{l}\text { Flushing, Headache, } \\
\text { Tachycardia }\end{array}$ \\
\hline \multicolumn{6}{|l|}{ Vasodilators } \\
\hline Enalaprilat & ACE Inhibitor & $0.625-5 \mathrm{mg} \mathrm{q} 6 \mathrm{hr}$ & $15-30 \mathrm{~min}$ & $4-6 \mathrm{hrs}$ & $\begin{array}{l}\text { Angioedema, cough, } \\
\text { renal failure }\end{array}$ \\
\hline Fenoldopam & Dopamine-1 agonist & $0.1-0.3 \mathrm{mcg} / \mathrm{kg} / \mathrm{min}$ & $5-10 \mathrm{~min}$ & $30 \mathrm{~min}$ & $\begin{array}{l}\text { Nausea, Headache, } \\
\text { Tachycardia, } \\
\text { phlebitis, } \\
\text { hypokalemia }\end{array}$ \\
\hline Hydralazine & Arteriolar vasodilation & $\begin{array}{l}5-20 \mathrm{mg} \text { bolus or } 10-40 \mathrm{mg} \\
\text { IM, repeat q4-6hrs }\end{array}$ & $10-20 \mathrm{~min}$ & $1-4 \mathrm{hrs}$ & $\begin{array}{l}\text { Flushing, Headache, } \\
\text { Tachycardia, } \\
\text { nausea/vomiting, } \\
\text { sodium and water } \\
\text { retention, increases } \\
\text { intracranial pressure }\end{array}$ \\
\hline Sodium nitroprusside & $\begin{array}{l}\text { Direct arterial and } \\
\text { venodilator }\end{array}$ & $\begin{array}{l}0.25-10 \mathrm{mcg} / \mathrm{kg} / \mathrm{min} \\
\text { infusion }\end{array}$ & Immediate & $1-2 \mathrm{~min}$ & $\begin{array}{l}\text { Thiocyanate and } \\
\text { cyanide toxicity, } \\
\text { methemoglobinemia, } \\
\text { nausea, vomiting }\end{array}$ \\
\hline
\end{tabular}

Table 5B. Oral Medications for Hypertensive Urgency

\begin{tabular}{|c|c|c|c|c|c|}
\hline Drug & Mechanism of Action & Dosage & Onset & Duration of Action & Adverse Reactions \\
\hline \multicolumn{6}{|l|}{ Vasodilators } \\
\hline Amlodipine & $\begin{array}{l}\text { Calcium channel } \\
\text { blocker }\end{array}$ & $5-10 \mathrm{mg}$ & $30-50 \mathrm{~min}$ & 18-24hrs & $\begin{array}{c}\text { Headache, flushing, } \\
\text { Tachycardia, } \\
\text { Peripheral edema }\end{array}$ \\
\hline Captopril & ACE Inhibitor & $12.5-50 \mathrm{mg}$ & $15-60 \mathrm{~min}$ & 4-6 hrs & Same as Enalaprilat \\
\hline Nicardipine & $\begin{array}{l}\text { Calcium channel } \\
\text { blocker }\end{array}$ & $20-30 \mathrm{mg}$ & $30-120 \mathrm{~min}$ & 6-8hrs & $\begin{array}{l}\text { Headache, } \\
\text { tachycardia }\end{array}$ \\
\hline Labetalol & Beta Blocker & $200-400 \mathrm{mg}$ & $20-120 \mathrm{~min}$ & $8-12 \mathrm{hrs}$ & $\begin{array}{c}\text { Bronchospasm, heart } \\
\text { block }\end{array}$ \\
\hline Furosemide & Diuretic & $20-40 \mathrm{mg}$ & $30-60 \mathrm{~min}$ & 4-6 hrs & As above \\
\hline
\end{tabular}


Table 6. Management of Clinical Conditions in Hypertensive Emergency

\begin{tabular}{|c|c|c|c|c|}
\hline Presentation & Clinical Diagnosis & Preferred Drug(s) & Drug(s) Less Preferred/to be Avoided & Target Blood Pressure \\
\hline $\begin{array}{l}\text { Chest Pain radiating } \\
\text { to left arm/back, } \\
\text { EKG findings }\end{array}$ & $\begin{array}{l}\text { Acute Myocardial } \\
\text { Infarction }\end{array}$ & $\begin{array}{l}\text { Esmolol, Labetolol, } \\
\text { Nitroglycerine* }\end{array}$ & Hydralazine & $\begin{array}{l}10-15 \% \text { Gradual reduction } \\
\text { of MAP }\end{array}$ \\
\hline $\begin{array}{l}\text { Severe back pain, } \\
\text { Dizziness, BP } \\
\text { difference between } \\
\text { arms }\end{array}$ & Aortic Dissection & $\begin{array}{l}\text { Nitroprusside and } \\
\text { labetolol/esmolol }\end{array}$ & Hydralazine & $\begin{array}{l}\mathrm{SBP}<120 \text { within } 20-30 \\
\text { minutes, } \mathrm{HR}<60 / \mathrm{min}\end{array}$ \\
\hline $\begin{array}{l}\text { Hematuria, red blood } \\
\text { cell casts, elevated } \\
\text { serum creatinine }\end{array}$ & Acute Glomerulonephritis & $\begin{array}{l}\text { Nicardipine } \\
\text { Fenoldopam } \\
\text { Enalaprilat** }\end{array}$ & Nitroprusside & $\begin{array}{l}10-15 \% \text { Gradual reduction } \\
\text { of MAP over hours }\end{array}$ \\
\hline $\begin{array}{l}\text { Agitation, chest } \\
\text { pressure, marked } \\
\text { tachycardia, drug use }\end{array}$ & Cocaine Withdrawal & Phentolamine & Beta blockers & $\begin{array}{l}10-15 \% \text { gradual reduction } \\
\text { of MAP }\end{array}$ \\
\hline $\begin{array}{l}>20 \text { weeks } \\
\text { pregnancy with } \\
\text { seizures }\end{array}$ & Eclampsia & $\begin{array}{l}\text { Labetolol, Magnesium } \\
\text { suphate, Nicardipine, } \\
\text { Hydralazine }\end{array}$ & $\begin{array}{l}\text { Nitroprusside, } \\
\text { Enalaprilat }\end{array}$ & $\mathrm{DBP}<90 \mathrm{~mm} \mathrm{Hg}<1$ hour \\
\hline $\begin{array}{l}\text { AMS, Papilledema, } \\
\text { headache, Seizures }\end{array}$ & $\begin{array}{l}\text { Hypertensive } \\
\text { Encephalopathy }\end{array}$ & $\begin{array}{l}\text { Labetolol, Nicardipine, } \\
\text { Fenoldopam }\end{array}$ & $\begin{array}{l}\text { Clonidine, } \\
\text { Hydralazine } \\
\text { Nitroprusside, Nitroglycerin }\end{array}$ & $\begin{array}{l}\text { Reduce } 25 \% \text { MAP in 2- } \\
3 \text { hrs }\end{array}$ \\
\hline $\begin{array}{l}\text { AMS, Headache, } \\
\text { Neurological Deficit }\end{array}$ & Intracranial Hemorrhage & $\begin{array}{l}\text { Esmolol, Labetolol, } \\
\text { Nicardipine if } \mathrm{SBP}>200 \\
\mathrm{~mm} \mathrm{Hg} \text { or } \\
\mathrm{MAP}>150 \mathrm{~mm} \mathrm{Hg}\end{array}$ & $\begin{array}{l}\text { Hydralazine } \\
\text { Nitroprusside, Nitroglycerin }\end{array}$ & $\begin{array}{l}\text { If High ICP: maintain } \\
\mathrm{MAP}<130 \mathrm{~mm} \mathrm{Hg} \text { or } \\
\mathrm{SBP}<180 \mathrm{~mm} \mathrm{Hg} \text { for first } \\
24 \mathrm{hrs} \\
\text { Normal ICP: } \mathrm{MAP}<110 \\
\mathrm{~mm} \mathrm{Hg} \text { or } \mathrm{SBP}<160 \mathrm{~mm} \\
\mathrm{Hg}\end{array}$ \\
\hline $\begin{array}{l}\text { AMS, } \\
\text { Headache, } \\
\text { Neurological Deficit }\end{array}$ & Ischemic Stroke & $\begin{array}{l}\text { Labetolol, Nicardipine } \\
\text { if BP }>180 / 120 \mathrm{~mm} \mathrm{Hg} \\
\text { or MAP }>140 \mathrm{~mm} \mathrm{Hg}\end{array}$ & Clonidine & $\begin{array}{l}15 \% \text { reduction in } \mathrm{MAP}, \\
\text { maintain } \mathrm{BP}<180 / 100 \mathrm{~mm} \\
\mathrm{Hg} \text { for } 24 \mathrm{hrs} \text { after } \\
\text { thrombolysis }\end{array}$ \\
\hline $\begin{array}{l}\text { Shortness of Breath, } \\
\text { rales, S3 gallop }\end{array}$ & $\begin{array}{l}\text { Pulmonary edema/heart } \\
\text { Failure }\end{array}$ & $\begin{array}{l}\text { Furosemide } \\
\text { ACE Inhibitor } \\
\text { Nitroglycerine } \\
\text { Nitroprusside }\end{array}$ & Beta Blockers & $10-15 \%$ reduction in MAP \\
\hline $\begin{array}{l}\text { Headache, } \\
\text { Sweating }\end{array}$ & Pheochromocytoma & $\begin{array}{l}\text { Labetolol, } \\
\text { Phentolamine }\end{array}$ & $\begin{array}{l}\text { Diuretics, } \\
\text { Nitroprusside }\end{array}$ & $\begin{array}{l}\text { Gradual reduction until } \\
\text { symptoms improve }\end{array}$ \\
\hline $\begin{array}{l}\text { AMS, } \\
\text { Headache, } \\
\text { Neurological Deficit }\end{array}$ & Subarachnoid hemorrhage & $\begin{array}{l}\text { Nimodipine Esmolol, } \\
\text { labetolol, nicardipine }\end{array}$ & $\begin{array}{l}\text { Hydralazine, } \\
\text { Nitroprusside, Nitroglycerin }\end{array}$ & $\begin{array}{l}\text { Maintain } \mathrm{SBP}<160 \mathrm{~mm} \\
\mathrm{Hg}, \mathrm{MAP}<130 \mathrm{~mm} \mathrm{Hg}, \\
\text { avoid MAP }<70 \mathrm{~mm} \mathrm{Hg}\end{array}$ \\
\hline
\end{tabular}

Laboratory investigations (Table 4) include complete blood count (CBC) with peripheral smear for the presence of anemia and schistocytes suggesting microangiopathic hemolytic anemia. Serum electrolytes, creatinine, glucose, urinalysis including toxicology, and blood urea nitrogen (BUN) should be assessed. Hypokalemic metabolic alkalosis may be seen in cases of pheochromocytoma and renovascular hypertension due to volume depletion. An electrocardiogram (EKG) should be performed to evaluate myocardial ischemia and left ventricular hypertrophy. Chest radiography may show widened mediastinum suggestive of aortic dissection or increased interstitial markings from pulmonary edema. Brain CT and MRI are helpful in patients with neurological manifestations, but should not be performed routinely in every patient.

\section{Therapeutic Management}

As discussed earlier, the clinical condition, not the absolute blood pressure, should govern the rapidity with which blood pressure should be controlled in hypertensive crises. There is some dispute on how quickly and to what degree the blood pressure should be lowered due to lack of clinical outcome studies. The goal is to avoid overaggressive treatment of the non emergent patient while initiating the most appropriate treatment in patients with end organ dysfunction. Table $\mathbf{5 A}$ and $\mathbf{B}$ summarizes the characteristics of intravenous and oral drugs used in the management of hypertensive crises.

\section{Hypertensive Emergency}

Due to lack of clinical studies investigating optimum therapy in hypertensive emergency, therapy is not evidencebased and in general is largely based on consensus statements of the Seventh Report of the Joint National Committee on Detection, Evaluation and Treatment of High Blood Pressure [43].

Patients presenting with hypertensive emergency should be admitted to the medical intensive care unit. Intravenous 
medications, with invasive arterial pressure monitoring are the preferred therapeutic agents for controlled, predictable, and safe blood pressure reduction. Generally, extra cerebral end organ damage or dysfunction benefits most from rapid blood pressure lowering. Depending on the nature of end organ damage one drug might have preference over others. Table $\mathbf{6}$ summarizes the management strategies, including preferred drugs in hypertensive emergencies with different clinical scenarios. Nitroprusside can be used in many instances due to its short half-life. Cyanate and thiocyanate toxicity are rare and most often noted following continuous infusion for long periods (days), and more so in patients with hepatic and renal dysfunction [44]. Diuretics should be used only in patients with heart failure and pulmonary edema; as patients tend to be hypovolemic as a result of hypertension - induced natriuresis. Moreover, fluid replacement has been shown to lower blood pressure and improve renal function in patients with severe hypertension and evidence of hypovolemia [44].

\section{POSTERIOR REVERSIBLE ENCEPHALOPATHY SYNDROME (PRES)}

This syndrome is characterized by headache, blurred vision, vomiting, seizures, altered mental status, and diffusion weighted MRI findings of edema in the white matter perfused by the posterior circulation.

Uncontrolled hypertension is the most common cause of this syndrome but it is also seen in the absence of hypertension with nephritic syndrome, systemic lupus erythematosus, sepsis, and immunosuppressant drug use [47].

\section{Pathophysiology}

As per the widely accepted vasogenic theory, breakdown of the normal blood brain barrier results in vasogenic edema which has apparent predisposition for occipitoparietal areas in the posterior circulation $[48,49]$. This could be secondary to the partial lack of sympathetic innervations of the vasculature which arise from the basilar artery system. Alternatively, the cytotoxic theory suggests that an acute rise in blood pressure leads to hypoperfusion causing hypoxia and subsequent endothelial damage which ultimately results in vasogenic edema.

Chronic hypertensive patients develop PRES at higher mean arterial pressures, usually $>150 \mathrm{~mm} \mathrm{Hg}$, as compared to normotensive patients with acute rise in blood pressure [47]. While usually reversible, the early recognition and treatment of this syndrome is important to prevent permanent neurological sequelae. It should be managed as any other hypertensive emergency in an ICU setting with short acting IV agents that are easily titrated to avoid precipitous fall in blood pressure.

\section{CONFLICT OF INTEREST}

The authors confirm that this article content has no conflict of interest.

\section{ACKNOWLEDGEMENTS}

Declared none.

\section{REFERENCES}

[1] Adams HPJ, Bendixen BH, Kappelle LJ, et al. Classification of subtype of acute ischemic stroke. Definitions for use in a multicenter clinical trial. TOAST. Trial of Org 10172 in Acute Stroke Treatment. Stroke 1993; 24(1): 35-41.
[2] Feigin VL, Lawes CM, Bennett DA, Anderson CS. Stroke epidemiology: a re- view of population-based studies of incidence, prevalence, and case-fatality in the late 20th century. Lancet Neurol 2003; 2(1): 43-5.

[3] Obrist WD, Langfitt TW, Jaggi JL, Cruz J, Gennarelli TA. Cerebral blood flow and metabolism in comatose patients with acute head injury. Relationship to intracranial hypertension. J Neurosurg 1984; 61(2): 24153.

[4] Dávalos A, Cendra E, Teruel J, Martinez M, Genís D. Deteriorating ischemic stroke: risk factors and prognosis. Neurology 1990; 40(12): $1865-69$.

[5] Jauch EC, Saver JL, Adams HPJ, et al. Guidelines for the early management of patients with acute ischemic stroke: a guideline for healthcare professionals from the American Heart Association/American Stroke Association. Stroke 2013; 44(3): 870947.

[6] Leonardi-Bee J, Bath PM, Phillips SJ, Sandercock PA, Group IST Collaborative. Blood pressure and clinical outcomes in the International Stroke Trial. Stroke 2002; 33(5): 1315-20.

[7] Willmot M, Leonardi-Bee J, Bath PM. High blood pressure in acute stroke and subsequent outcome: a systematic review. Hypertension. 2004; 43(1): 18-24.

[8] Castillo J, Leira R, García MM, Serena J, Blanco M, Dávalos A. Blood pressure decrease during the acute phase of ischemic stroke is associated with brain injury and poor stroke outcome. Stroke 2004; 35(2): 520-6.

[9] Vemmos KN, Tsivgoulis G, Spengos K, et al. U-shaped relationship between mortality and admission blood pressure in patients with acute stroke. J Intern Med 2004; 255(2): 257-65.

[10] Okumura K, Ohya Y, Maehara A, Wakugami K, Iseki K, Takishita S. Effects of blood pressure levels on case fatality after acute stroke. J Hypertens 2005; 23(6): 1217-23.

[11] Kaste M, Fogelholm R, Erilä T, et al. A randomized, double-blind, placebo-controlled trial of nimodipine in acute ischemic hemispheric stroke. Stroke 1994; 25(7): 1348-53.

[12] Sandset EC, Bath PM, Boysen G, et al. The angiotensin-receptor blocker candesartan for treatment of acute stroke (SCAST): a randomised, placebo-controlled, double-blind trial. Lancet 2011; 377(9767): 741-50.

[13] Potter JF, Robinson TG, Ford GA, et al. Controlling hypertension and hypotension immediately post-stroke (CHHIPS): a randomised, placebo-controlled, double-blind pilot trial. Lancet Neurol 2009; 8(1): 48-56.

[14] Robinson TG, Potter JF, Ford GA, et al. Effects of antihypertensive treatment after acute stroke in the Continue or Stop Post-Stroke Antihypertensives Collaborative Study (COSSACS): a prospective, randomised, open, blinded-endpoint trial. Lancet Neurol 2010; 9(8):767-75.

[15] ENOS Trial Investigators. Glyceryl trinitrate $v s$ control, and continuing $v s$ stopping temporarily prior antihypertensive therapy, in acute stroke: rationale and design of the Efficacy of Nitric Oxide in Stroke (ENOS) trial (ISRCTN99414122). Int J Stroke 2006; 1(4): 245-9.

[16] European Stroke Organisation (ESO) Executive Committee. Guidelines for management of ischaemic stroke and transient ischaemic attack 2008. Cerebrovasc Dis 2008; 25(5): 457-507.

[17] Patarroyo SX, Anderson C. Blood pressure lowering in acute phase of stroke: latest evidence and clinical implications. Ther Adv Chronic Dis 2012; 3(4): 163-71.

[18] Jung SY, Choi NK, Kim JY, et al. Short-acting nifedipine and risk of stroke in elderly hypertensive patients. Neurology 2011; 77(13): 122934.

[19] Rordorf G, Cramer SC, Efird JT, Schwamm LH, Buonanno F, Koroshetz WJ. Pharmacological elevation of blood pressure in acute stroke. Clinical effects and safety. Stroke 1997; 28(11): 2133-8.

[20] Rordorf G, Koroshetz WJ, Ezzeddine MA, Segal AZ, Buonanno FS. A pilot study of drug-induced hypertension for treatment of acute stroke. Neurology 2001; 56(9): 1210-3.

[21] Marzan AS, Hungerbühler HJ, Studer A, Baumgartner RW, Georgiadis D. Feasibility and safety of norepinephrine-induced arterial hypertension in acute ischemic stroke. Neurology 2004; 62(7): 1193-5.

[22] Hillis AE, Ulatowski JA, Barker PB, et al. A pilot randomized trial of induced blood pressure elevation: effects on function and focal perfusion in acute and subacute stroke. Cerebrovasc Dis 2003; 16(3): $236-46$. 
[23] Koenig MA, Geocadin RG, DeGrouchy M, et al. Safety of induced hypertension therapy in patients with acute ischemic stroke. Neurocrit Care 2006; 4(1): 3-7.

[24] Qureshi AI, Ezzeddine MA, Nasar A, et al. Prevalence of elevated blood pressure in 563,704 adult patients with stroke presenting to the ED in the United States. Am J Emerg Med 2007; 25(1): 32-8.

[25] Naidech AM, Janjua N, Kreiter KT, et al. Predictors and impact of aneurysm rebleeding after subarachnoid hemorrhage. Arch Neurol 2005; 62(3): 410-6.

[26] Bederson JB, Connolly ESJ, Batjer HH, et al. Guidelines for the management of aneurysmal subarachnoid hemorrhage: a statement for healthcare professionals from a special writing group of the Stroke Council, American Heart Association. Stroke 2009; 40(3): 994-1025.

[27] Ohkuma H, Tsurutani H, Suzuki S. Incidence and significance of early aneurysmal rebleeding before neurosurgical or neurological management. Stroke 2001; 32(5): 1176-80.

[28] Heuer GG, Smith MJ, Elliott JP, Winn HR, LeRoux PD. Relationship between intracranial pressure and other clinical variables in patients with aneurysmal subarachnoid hemorrhage. J Neurosurg 2004; 101(3): 408-16.

[29] Treggiari MM. Participants in the International Multi-disciplinary Consensus Conference on the Critical Care Management of Subarachnoid Hemorrhage. Hemodynamic management of subarachnoid hemorrhage. Neurocrit Care 2011; 15(2): 329-35.

[30] Hocker S, Morales-Vidal S, Schneck MJ. Management of arterial blood pressure in acute ischemic and hemorrhagic stroke. Neurol Clin 2010; 28(4): 863-86.

[31] Otsubo H, Takemae $\mathrm{T}$, Inoue $\mathrm{T}$, Kobayashi $\mathrm{S}$, Sugita K. Normovolaemic induced hypertension therapy for cerebral vasospasm after subarachnoid haemorrhage. Acta Neurochir (Wien) 1990; 103(12): $18-26$.

[32] Bullock MR, Chesnut R, Ghajar J, et al. Surgical management of acute epidural hematomas. Neurosurgery 2006; 58(3 Suppl): S7-15.

[33] Wilberger JEJ, Harris M, Diamond DL. Acute subdural hematoma: morbidity, mortality, and operative timing. J Neurosurg 1991; 74(2): 212-8.

[34] Croce MA, Dent DL, Menke PG, et al. Acute subdural hematoma: nonsurgical management of selected patients. J Trauma 1994; 36(6): 820-6.

[35] Ohwaki K, Yano E, Nagashima H, Hirata M, Nakagomi T, Tamura A. Blood pressure management in acute intracerebral hemorrhage: relationship between elevated blood pressure and hematoma enlargement. Stroke 2004; 35(6): 1364-7.

[36] Anderson CS, Huang Y, Wang JG, et al. Intensive blood pressure reduction in acute cerebral haemorrhage trial (INTERACT): a randomised pilot trial. Lancet Neurol 2008; 7(5): 391-9.
[37] Anderson CS, Huang Y, Arima H, et al. Effects of early intensive blood pressure-lowering treatment on the growth of hematoma and perihematomal edema in acute intracerebral hemorrhage: the Intensive Blood Pressure Reduction in Acute Cerebral Haemorrhage Trial (INTERACT). Stroke 2010; 41(2): 307-12.

[38] Broderick J, Connolly S, Feldmann E, et al. Guidelines for the management of spontaneous intracerebral hemorrhage in adults: 2007 update: a guideline from the American Heart Association/American Stroke Association Stroke Council, High Blood Pressure Research Council, and the Quality of Care and Outcomes in Research Interdisciplinary Working Group. Stroke 2007; 38(6): 2001-23.

[39] Qureshi AI, Mohammad YM, Yahia AM, et al. A prospective multicenter study to evaluate the feasibility and safety of aggressive antihypertensive treatment in patients with acute intracerebral hemorrhage. J Intensive Care Med 2005; 20(1): p. 34-42.

[40] Anderson CS, Heeley E, Huang Y, et al. Rapid blood-pressure lowering in patients with acute intracerebral hemorrhage. N Engl J Med 2013; 368(25): 2355-65.

[41] Frontera JA. Blood pressure in intracerebral hemorrhage--how low should we go? N Engl J Med 2013; 369(13): 1275.

[42] Zampaglione B, Pascale C, Marchisio M, Cavallo-Perin P. Hypertensive urgencies and emergencies. Prevalence and clinical presentation. Hypertension 1996; 27(1): 144-7.

[43] Lenfant C, Chobanian A V, Jones DW, Roccella EJ. Joint National Committee on the Prevention Detection Evaluation and Treatment of High Blood Pressure. Seventh report of the Joint National Committee on the Prevention, Detection, Evaluation, and Treatment of High Blood Pressure (JNC 7): resetting the hypertension sails. Hypertension 2003; 41(6): 1178-9.

[44] Vaughan CJ, Delanty N. Hypertensive emergencies. Lancet 2000; 356(9227): 411-7.

[45] Ault MJ, Ellrodt AG. Pathophysiological events leading to the endorgan effects of acute hypertension. Am J Emerg Med 1985; 3(6 Suppl): 10-5.

[46] Fleming S. Malignant hypertension - the role of the paracrine reninangiotensin system. J Pathol 2000; 192(2): 135-9.

[47] Pedraza R, Marik PE, Varon J. Posterior Reversible Encephalopathy Syndrome: A Review. Crit Care Shock 2009; 12(4): 135-43.

[48] Stott VL, Hurrell MA, Anderson TJ. Reversible posterior leukoencephalopathy syndrome: a misnomer reviewed. Intern Med J 200; 35(2): 83-90.

[49] Doelken M, Lanz S, Rennert J, Alibek S, Richter G, Doerfler A. Differentiation of cytotoxic and vasogenic edema in a patient with reversible posterior leukoencephalopathy syndrome using diffusionweighted MRI. Diagn Interv Radiol 2007; 13(3): 125-8. 